\title{
What are the Main Determinants of Renewable Energy Consumption? A Panel Threshold Regression Approach ${ }^{1}$
}

\author{
Yenilenebilir Enerji Tüketiminin Başlıca Belirleyicileri Nelerdir? \\ Panel Eşik Regresyon Yaklaşımı
}

\section{Araş. Gör. Dr. Gülsüm Akarsu² - Dr. Öğr. Üyesi Nebile Korucu Gümüşoğlu}

Başvuru Tarihi: 13.06.2018

Kabul Tarihi: 18.02.2019

\begin{abstract}
Because of severe environmental impacts associated with the use of conventional energy sources, most of the countries attempt to decarbonize their energy sector by increasing share of renewable energy in their total energy consumption which also reduces their energy import dependency. Therefore, this study aims to understand the determinants of renewable energy consumption for 58 countries over the period from 1990 to 2012. The period and number of countries are determined based on the data availability for all the variables. For example, data on total greenhouse gas emissions is available only up to 2012. Analysis is based on a panel threshold regression model to find out asymmetric behavior of renewable energy consumption. The model explains renewable energy consumption by various economic factors in a nonlinear framework. Different effects of these factors are expected under different economic regimes characterized by income level. Results show that for real GDP per capita lower than 1527.977 US\$, signs, statistical significance and magnitude of coefficients on some variables differ tremendously compared to the upper regime verifying the asymmetric relationship. Therefore, one can conclude that determinants of renewable energy consumption differ across countries and time based on the real GDP per capita level.
\end{abstract}

Keywords: Renewable Energy Consumption, Panel Threshold Regression Model, Economic Factors

\footnotetext{
1 This study was presented in Fifth International Conference in Economics (Econ Anadolu 2017) held in Eskisehir, Turkey between 11th and 13th May 2017 and in 7th International \%100 Renewable Energy Conference (IRENEC 2017) held in İstanbul, Turkey between 18th and 20th May, 2017. Authors would like to thank to all the participants for their helpful comments.

2 Ondokuz Mayıs Üniversitesi İİBF, akarsu.gulsum@gmail.com, ORCID: 0000-0002-4877-1969

${ }^{3}$ İstanbul Kültür Üniversitesi İİBF, nkorucu@gmail.com, ORCID: 0000-0003-3308-4362
} 
Öz

Fosil yakıtların kullanımından kaynaklanan çevresel etkilerden dolayı, birçok ülke, aynı zamanda enerjide dışa bağımlılı̆̆ın azaltmasını da sağlayabilmek amacıyla yenilenebilir enerji kaynaklarının oranını artırarak, enerji sektörlerinde sera gazını azaltmaya çabalamaktadır. Bu nedenle, bu çalışma, 1990 ve 2012 dönemleri arasında 58 ülke için yenilebilir enerji tüketiminin belirleyicilerini analiz etmeyi amaçlamaktadır. Yenilenebilir enerji tüketiminde simetrik olmayan davranışı dikkate alabilmek amacıyla analiz panel eşik regresyon modeline dayanmaktadır. Modelde doğrusal olmayan çerçevede, yenilenebilir enerji tüketimi, birçok iktisadi faktör tarafından açıklanmıştır. Gelir seviyesine göre belirlenen iktisadi rejimler için bütün faktörlerin farklı etkilere sahip olması beklenmektedir. Sonuçlar, kişi başına GSYİH'nın (sabit 2010 US \$ cinsinden) 1527.977 seviyesinden düşük olduğu durumlarda bazı değişkenlerin katsayılarının işareti, istatistiksel anlamlılığı ve boyutu, o seviyeden yüksek olduğu rejime kıyasla farklılaşabilmekte, bu ise, simetrik olmayan ilişkinin bulunduğunu göstermektedir. Dolayısıla, yenilenebilir enerji tüketiminin belirleyicileri reel kişi başına GSYİH'a bağlı olarak, ülkeler arasında ve zaman boyunca değiştiği sonucuna ulaşılmıştır.

Anahtar Kelimeler: Yenilenebilir Enerji Tüketimi, Panel Eşik Regresyon Modeli, İktisadi Faktörler

\section{Introduction}

Due to the climate change and environmental problems caused by the heavy use of fossil fuels renewable energy has gained an important share in the energy consumption mix of many countries being an alternative source of energy. In addition, renewable energy has some other advantages, such as economic growth effects and providing energy access to people unable to benefit from modern energy services (REN21, 2015). As renewable energy technologies provide off-grid or mini-grid systems, rural electrification can be improved which also contributes to the development of rural regions (Ackah and Kizys, 2015). The main aim of this study is to understand the major economic factors inducing the consumption of renewable energy in the context of cross-country analysis.

Technology improvement in renewable energy and investment cost decline leads to high investments in renewable energy technologies for year 2016 and similarly in 2014 despite of falling oil prices (REN21, 2014, 2015, 2017). World renewable energy consumption share increases from $17 \%$ to $18 \%{ }^{4}$ between 1990 and 2014 . However, this increase is not sufficient to reach the goal of UN's Sustainable Energy for All (SE4ALL) initiative for year 2030 according to REN21 (2015) report. Figure 1 illustrates the share of renewables used in the total energy production across the countries for year 2014. One can observe that renewable energy has the dominant share in countries such as China, India and United States. For new capacity additions in 2014 also, China, Brazil, India, and South Africa are top four countries (REN21, 2015). But there are significant differences in the share of renewable energy among the countries as seen

\footnotetext{
${ }^{4}$ These values are calculated using data obtained from World Bank World Development Indicators Database.
} 
from Figure 1. Therefore, this study attempts to understand these differences in the context of an economic model. Moreover, in order to increase the share of renewables, most of the countries implement various support mechanisms ${ }^{5}$, for example, subsidies, direct investment, research and development, green certificates, Feed-in-Tariffs and Renewable Obligation Schemes (da Silva et al., 2018). The main aims of these support mechanisms are to increase renewable energy investments by making renewables cost competitive compared to traditional energy sources, increase their market share and also public awareness and acceptance, ensure the energy transition by promoting sustainable energy systems based on mostly on renewables, develop competitive market and new renewable energy technologies (Carley, 2009; Gan and Smith, 2011). For example, in Feed-in-Tariffs support mechanism, renewable energy projects are supported by purchase guarantee at fixed prices during a predetermined period which may increase the profitability and decrease the risk of the project. In this way, energy production from renewables may also raise which may result in renewable energy consumption increase. For more information, one can refer to Marques and Fuinhas (2012) and Gan and Smith (2011). In the literature, some studies (Aguirre and Ibikunle, 2014; Carley, 2009; Kim and Park, 2016; Marques and Fuinhas, 2012; Marques et al., 2010; Pfeiffer and Mulder, 2013; da Silva et al., 2018) also consider the impacts of political factors and support mechanisms on the renewable energy consumption, explicitly. On the other hand, other studies analyze solely the determinants of renewable energy consumption without distinguishing the effects of various political instruments (Ackah and Kizys, 2015; Akar, 2016; Apergis and Payne, 2014a, 2014b; Bengochea and Faet, 2012; Chang et al., 2009; Omri et al., 2015; Omri and Nguyen, 2014; Sadorsky, 2009a, 2009b; Salim and Rafiq, 2012). This study also focuses mostly on economic factors. Political factors are included into the analysis as country-specific factors.

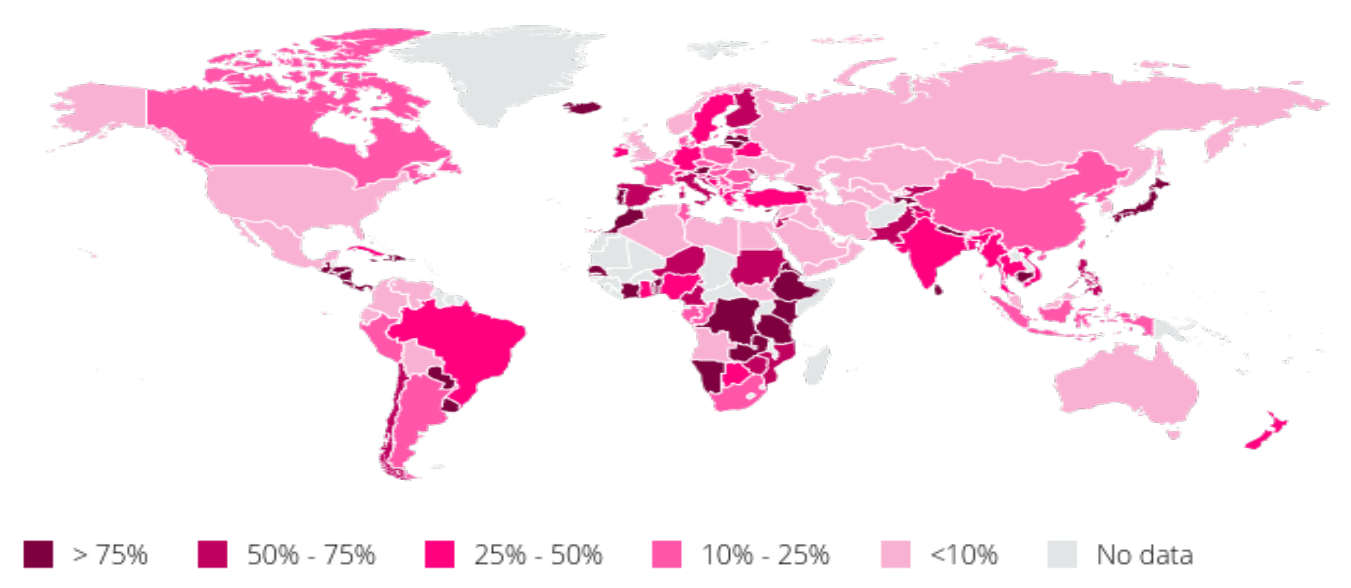

Figure 1. Renewables' Share in Total Energy Production (\%) for 2014

Source: International Energy Agency

In the literature, studies are performed for different countries covering different time periods and using various methods. Factors included into the models of these studies can be categorized

${ }^{5}$ One can refer to Sawin (2004) for detailed information on renewable energy support mechanisms. 
as political, socioeconomic and country-specific factors (Aguirre and Ibikunle, 2014; Marques et al., 2010). Table 1 shows the information on recent studies. Real income was found to be one of the main drivers of renewable energy consumption by most of the studies (Ackah and Kizys, 2015; Apergis and Payne, 2014a, 2014b; Carley, 2009; da Silva et al., 2018; Gan and Smith, 2011; Omri et al., 2015; Omri and Nguyen, 2014; Pfeiffer and Mulder, 2013; Sadorsky, 2009a, 2009b; Salim and Rafiq, 2012). Growing population and income necessitates energy consumption increase (Apergis and Payne, 2014b; Sadorsky, 2009a; Salim and Rafiq, 2012) and for developmental sustainability, most of countries prefer to utilize renewable energy resources in order to meet their energy requirements (Ackah and Kizys, 2015; Sadorsky, 2009b). Moreover, high income countries may finance the costly renewable energy investments easily and can provide incentives because of availability of sources, therefore, as income increases, countries may employ higher amount of renewables (Aguirre and Ibikunle, 2014; Carley, 2009; da Silva et al., 2018; Marques and Fuinhas, 2011; Marques et al., 2010). Moreover, high income countries may have higher environmental awareness which may be regarded as one of the factors contributing to higher use of renewables in these countries (Pfeiffer and Mulder, 2013).

Table 1. Recent Studies on the Determinants of Renewable Energy Consumption

\begin{tabular}{|c|c|c|c|c|}
\hline Author & Years & Country & Model/Method & Main Findings \\
\hline $\begin{array}{l}\text { Carley } \\
\text { (2009) }\end{array}$ & $\begin{array}{l}1998- \\
2006\end{array}$ & $\begin{array}{l}50 \text { US } \\
\text { states }\end{array}$ & $\begin{array}{l}\text { Fixed Effects } \\
\text { Vector } \\
\text { Decomposition }\end{array}$ & $\begin{array}{l}\text { Renewable portfolio standard policy implementation } \\
\text { was found to be ineffective to increase the share of } \\
\text { renewable energy production. The results showed } \\
\text { significance of other factors' negative impacts, such } \\
\text { as, per capita electricity consumption, petroleum and } \\
\text { coal manufacturing shares, deregulation, renewable } \\
\text { energy potential and tax incentive program in } \\
\text { addition to the positive effects of real income and } \\
\text { policy measures and negative effect of electricity } \\
\text { price. }\end{array}$ \\
\hline $\begin{array}{l}\text { Chang et al. } \\
(2009)\end{array}$ & $\begin{array}{l}1997- \\
2006\end{array}$ & $\begin{array}{l}\text { OECD } \\
\text { countries }\end{array}$ & $\begin{array}{l}\text { Panel } \\
\text { Threshold } \\
\text { Regression } \\
\text { Model }\end{array}$ & $\begin{array}{l}\text { The effects of energy prices on share of renewable } \\
\text { energy supply were found to change according to } \\
\text { economic regimes based on economic growth in such } \\
\text { a way that in high growth regime, energy prices have } \\
\text { positive and significant effect, whereas in low growth } \\
\text { regime, negative and insignificant effects are found. }\end{array}$ \\
\hline $\begin{array}{l}\text { Sadorsky } \\
\text { (2009a) }\end{array}$ & $\begin{array}{l}1994- \\
2003\end{array}$ & $\begin{array}{l}18 \\
\text { Emerging } \\
\text { countries }\end{array}$ & $\begin{array}{l}\text { Panel } \\
\text { Cointegration } \\
\text { Model }\end{array}$ & $\begin{array}{l}\text { The results showed the evidence for the long run } \\
\text { relation between real income per capita and } \\
\text { renewable energy consumption per capita. } \\
\text { Moreover, findings indicated the absence of any } \\
\text { bidirectional short run causal relation between } \\
\text { income and renewable energy consumption and also } \\
\text { there is not any short run causality from electricity } \\
\text { price to renewable energy consumption. Lastly, short } \\
\text { run effect of real income on electricity prices was } \\
\text { found to be negative. }\end{array}$ \\
\hline $\begin{array}{l}\text { Sadorsky } \\
\text { (2009b) }\end{array}$ & $\begin{array}{l}1980- \\
2005\end{array}$ & $\begin{array}{l}\text { G7 } \\
\text { countries }\end{array}$ & $\begin{array}{l}\text { Error } \\
\text { Correction } \\
\text { Model, SUR }\end{array}$ & $\begin{array}{l}\text { Long run determinants of renewable energy } \\
\text { consumption per capita were found to be real income } \\
\text { per capita, real oil prices and } \mathrm{CO}_{2} \text { emissions per } \\
\text { capita. }\end{array}$ \\
\hline $\begin{array}{l}\text { Marques, } \\
\text { Fuinhas }\end{array}$ & $\begin{array}{l}1990- \\
2006\end{array}$ & $\begin{array}{l}24 \\
\text { European } \\
\text { countries }\end{array}$ & $\begin{array}{l}\text { Fixed Effects } \\
\text { Vector } \\
\text { Decomposition }\end{array}$ & $\begin{array}{l}\text { For European Union (EU) countries, their results } \\
\text { showed the negative effects of } \mathrm{CO}_{2} \text { emissions per } \\
\text { capita and oil prices as well as negative lobby effect }\end{array}$ \\
\hline
\end{tabular}


and Mans

(2010)

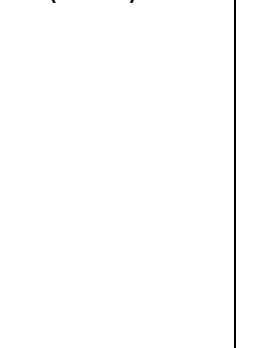

Gan and
Smith
(2011)

Marques

$1990-$

and

Fuinhas

(2011)

Bengochea

and Faet

(2012)

Marques

and

Fuinhas

(2012)

Salim and

1980-

Rafiq

(2012)

1990-

2004

1990

2007
24

European

countries

\begin{tabular}{|l|} 
\\
\end{tabular}

(2013)

European

Union

countries

23

European

countries

Six major

emerging

countries
OECD

countries

Static Panel

Data Model

Dynamic Panel

Data Model

Static Panel Data Models

Panel

Corrected Standard Errors Estimator

Panel (FMOLS, DOLS) and time series (ARDL model) techniques related to the fossil fuels. Positive effects are found for energy dependency, geographic area, real income, energy consumption per capita, continuous commitment to renewables, natural gas and coal prices. Different from EU countries, for non-EU countries, effect of oil price on the share of renewable energy supply was found to be insignificant and in addition, negative effects were found for real income, natural gas price, coal price and continuous commitment to renewables.

GDP per capita and renewable energy deployment policies are found to have positive and statistically significant effects along with factors specific to each country. However, the results indicate insignificance of the effects associated with changes in energy prices, government expenditures on $\mathrm{R} \& \mathrm{D}, \mathrm{CO}_{2}$ emissions, research and innovation policies and market-based policies.

This study's findings indicated statistically significant negative lobby effect, negative effect of $\mathrm{CO}_{2}$ emissions per capita and positive effect of energy use per capita. The effects of income, fossil fuel prices and energy imports were found to be insignificant. Results showed positive and statistically significant effect of $\mathrm{CO}_{2}$ emissions but the impact of fossil fuels price was found to be statistically insignificant.

Policies promoting renewables, per capita energy consumption and continuous commitment to renewables were found to affect renewable energy share positively and significantly. Negative and statistically significant effects were obtained for energy imports, lobby and per capita $\mathrm{CO}_{2}$ emissions. Results showed the presence of cointegrating relation between renewable energy consumption, real GDP, carbon emissions and real oil price. In the long run, carbon emissions and real GDP affect renewable energy consumption positively and statistically significantly for Brazil, China, India and Indonesia but only real GDP has a significant and positive effect for Turkey and Philippines. Moreover, bidirectional causality was found between renewable energy consumption and real GDP for Brazil, China, Philippines and Turkey. For Brazil, China, India and Indonesia, the results indicated bidirectional causality between renewable energy consumption and $\mathrm{CO}_{2}$ emissions. The findings showed bidirectional causality between real GDP and $\mathrm{CO}_{2}$ emissions for Brazil and China, unidirectional causality from real GDP to renewable energy consumption for India and Indonesia. But, for most of the countries, the effect of real oil price was found to be statistically insignificant. This study found positive and statistically significant effects of real income per capita, energy mix, educational attainment, economic incentive mechanisms and regulatory tools on the per capita electricity generated from renewables. The findings showed the negative and statistically significant effects of trade openness, foreign direct investment, 


\begin{tabular}{|c|c|c|c|c|}
\hline & & & & $\begin{array}{l}\text { policy support programs, growth of electricity } \\
\text { consumption and production from fossil fuels. } \\
\text { Financial development and Kyoto protocol was found } \\
\text { to have no statistically significant effects. }\end{array}$ \\
\hline $\begin{array}{l}\text { Aguirre and } \\
\text { lbikunle } \\
\text { (2014) }\end{array}$ & $\begin{array}{l}1990- \\
2010\end{array}$ & $\begin{array}{l}38 \\
\text { Countries } \\
\text { (Europe, } \\
\text { OECD, } \\
\text { BRICS) }\end{array}$ & $\begin{array}{l}\text { Fixed Effects } \\
\text { Vector } \\
\text { Decomposition, } \\
\text { Panel } \\
\text { Corrected } \\
\text { Standard Errors } \\
\text { estimator }\end{array}$ & $\begin{array}{l}\text { Results indicated the positive and statistically } \\
\text { significant effects of } \mathrm{CO}_{2} \text { emissions, continuous } \\
\text { commitment to renewables, ratification of Kyoto } \\
\text { protocol, negotiated agreements, biomass and solar } \\
\text { energy potential, whereas, negative effects of Fiscal, } \\
\text { Financial and Voluntary policy measures, energy } \\
\text { usage, lobby measured by the shares of coal, natural } \\
\text { gas, nuclear and crude oil in the energy generation, } \\
\text { wind energy potential and industrial electricity price. } \\
\text { On the other hand, some of the factors were found to } \\
\text { have insignificant effects, such as, energy imports, } \\
\text { energy prices, GDP per capita, population growth and } \\
\text { deregulation. }\end{array}$ \\
\hline $\begin{array}{l}\text { Apergis and } \\
\text { Payne } \\
\text { (2014a) }\end{array}$ & $\begin{array}{l}1980- \\
2011\end{array}$ & $\begin{array}{l}25 \text { OECD } \\
\text { countries }\end{array}$ & $\begin{array}{l}\text { Panel Error } \\
\text { Correction } \\
\text { Model }\end{array}$ & $\begin{array}{l}\text { This study's findings showed both long run and short } \\
\text { run statistically significant and positive effects of real } \\
\text { GDP per capita, } \mathrm{CO}_{2} \text { per capita and real oil prices on } \\
\text { per capita total renewable energy consumption in } \\
\text { addition to the bidirectional long run and short run } \\
\text { causalities between all the variables. In the long run, } \\
1 \% \text { increases in real GDP per capita, } \mathrm{CO}_{2} \text { per capita } \\
\text { and real oil prices lead to } 0.345 \%, 0.352 \% \text { and } 0.450 \% \\
\text { increases in the renewable energy consumption per } \\
\text { capita. }\end{array}$ \\
\hline $\begin{array}{l}\text { Apergis and } \\
\text { Payne } \\
\text { (2014b) }\end{array}$ & $\begin{array}{l}1980- \\
2010\end{array}$ & $\begin{array}{l}7 \text { Central } \\
\text { American } \\
\text { countries }\end{array}$ & $\begin{array}{l}\text { Panel Smooth } \\
\text { Transition } \\
\text { VECM }\end{array}$ & $\begin{array}{l}\text { In the long run, renewable energy consumption per } \\
\text { capita was found to be increased by increases in the } \\
\text { real GDP per capita, } \mathrm{CO}_{2} \text { per capita, real oil price and } \\
\text { real coal price. For the short run, the establishment of } \\
\text { Energy and Environment Partnership in } 2002 \text { affects } \\
\text { the results. There is evidence of long run and short } \\
\text { run bidirectional causality among all the variables } \\
\text { with one exception. Before } 2002 \text {, although there is } \\
\text { not any evidence of short run causality running from } \\
\text { real coal and oil prices to renewable energy } \\
\text { consumption per capita, after } 2002 \text {, the results } \\
\text { indicated the existence of bidirectional causality } \\
\text { between all of the variables. Long run estimation } \\
\text { results showed that } 1 \% \text { increases in real GDP per } \\
\text { capita, CO } \mathrm{CO}_{2} \text { per capita, real coal prices and real oil } \\
\text { prices are accompanied with } 0.376 \%, 0.219 \%, 0.153 \% \\
\text { and } 0.285 \% \text { increases in the per capita renewable } \\
\text { energy consumption. }\end{array}$ \\
\hline $\begin{array}{l}\text { Omri and } \\
\text { Nguyen } \\
\text { (2014) }\end{array}$ & $\begin{array}{l}1990- \\
2011\end{array}$ & $\begin{array}{l}64 \\
\text { Countries }\end{array}$ & $\begin{array}{l}\text { Dynamic Panel } \\
\text { Data Model }\end{array}$ & $\begin{array}{l}\text { Renewable energy consumption growth was found to } \\
\text { increase as a result of per capita } \mathrm{CO}_{2} \text { emissions } \\
\text { growth. Results showed statistically significant and } \\
\text { positive effect of trade openness for middle and low } \\
\text { income countries and for the full sample. Positive } \\
\text { influence of per capita GDP growth was found for high } \\
\text { and middle income countries. The findings indicated } \\
\text { the adverse effect of oil price growth for middle } \\
\text { income countries and for the full sample. }\end{array}$ \\
\hline $\begin{array}{l}\text { Ackah and } \\
\text { Kizys (2015) }\end{array}$ & $\begin{array}{l}1985- \\
2010\end{array}$ & $\begin{array}{l}\text { Oil } \\
\text { producing } \\
\text { African } \\
\text { countries }\end{array}$ & $\begin{array}{l}\text { Static and } \\
\text { Dynamic Panel } \\
\text { Data Models }\end{array}$ & $\begin{array}{l}\text { The findings showed that increases in real GDP per } \\
\text { capita, population, energy resource depletion per } \\
\text { capita and per capita capital stock lead to increase in } \\
\text { per capita renewable energy consumption. } \mathrm{CO}_{2}\end{array}$ \\
\hline
\end{tabular}




\begin{tabular}{|c|c|c|c|c|}
\hline & & & & $\begin{array}{l}\text { emissions per capita and energy prices affect } \\
\text { renewable energy consumption negatively. Results } \\
\text { showed the insignificance of human capital effect. }\end{array}$ \\
\hline $\begin{array}{l}\text { Omri et al. } \\
(2015)\end{array}$ & $\begin{array}{l}1990- \\
2011\end{array}$ & $\begin{array}{l}64 \\
\text { countries }\end{array}$ & $\begin{array}{l}\text { Static and } \\
\text { Dynamic Panel } \\
\text { Data Models }\end{array}$ & $\begin{array}{l}\text { For all subsamples (high, middle, low income } \\
\text { countries and all countries), per capita } \mathrm{CO}_{2} \text { emissions } \\
\text { growth and per capita real GDP growth were found to } \\
\text { have statistically significant effects on per capita } \\
\text { renewable energy consumption growth. } 1 \% \text { increase } \\
\text { in per capita } \mathrm{CO}_{2} \text { emissions increases per capita } \\
\text { renewable energy consumption by } 0.19 \text { to } 0.26 \% .1 \% \\
\text { increase in per capita real GDP lead to an increase } \\
\text { between } 0.20 \% \text { and } 0.42 \% \text {. Trade openness also } \\
\text { increases renewable energy consumption except in } \\
\text { high income countries. Lastly, real crude oil price } \\
\text { growth was found to have statistically significant and } \\
\text { positive effect for full sample of countries. }\end{array}$ \\
\hline Akar (2016) & $\begin{array}{l}1997- \\
2011\end{array}$ & $\begin{array}{l}\text { Balkan } \\
\text { countries }\end{array}$ & $\begin{array}{l}\text { Dynamic Panel } \\
\text { Data Model }\end{array}$ & $\begin{array}{l}\text { This study showed that trade openness and natural } \\
\text { gas rents have favorable and significant impacts on } \\
\text { renewable energy share, but economic growth } \\
\text { decreases the renewable energy share. Oil rents and } \\
\text { per capita } \mathrm{CO}_{2} \text { emissions were found to have } \\
\text { insignificant effects. }\end{array}$ \\
\hline $\begin{array}{l}\text { Kim and } \\
\text { Park (2016) }\end{array}$ & $\begin{array}{l}2000- \\
2013\end{array}$ & $\begin{array}{l}30 \\
\text { countries }\end{array}$ & $\begin{array}{l}\text { Tobit } \\
\text { Regression }\end{array}$ & $\begin{array}{l}\text { Results showed the positive and statistically } \\
\text { significant effects of Feed-in-Tariff support } \\
\text { mechanism, financial market development (overall, } \\
\text { credit and equity market) and electricity generation } \\
\text { share increase. Moreover, according to the findings, } \\
\text { by the international financing, renewable energy } \\
\text { deployment accelerates. In most of the cases, GDP } \\
\text { per capita was found as a major factor influencing the } \\
\text { renewable energy capacity. }\end{array}$ \\
\hline $\begin{array}{l}\text { da Silva et } \\
\text { al. (2018) }\end{array}$ & $\begin{array}{l}1990- \\
2014\end{array}$ & $\begin{array}{l}\text { Sub- } \\
\text { Saharan } \\
\text { Africa }\end{array}$ & $\begin{array}{l}\text { Panel ARDL } \\
\text { Model }\end{array}$ & $\begin{array}{l}\text { The findings indicated the presence of long run } \\
\text { relation between renewable energy share in } \\
\text { electricity generation, per capita real GDP, per capita } \\
\mathrm{CO}_{2} \text { emissions, energy prices (crude oil, natural gas } \\
\text { and coal prices), per capita energy use, population } \\
\text { growth, electricity import and Kyoto protocol } \\
\text { ratification. Real income per capita and energy use } \\
\text { per capita increase renewable energy share; whereas, } \\
\text { changes in per capita } \mathrm{CO}_{2} \text { emissions, energy prices, } \\
\text { population growth, electricity import and Kyoto } \\
\text { protocol ratification affect renewable energy use, } \\
\text { adversely. }\end{array}$ \\
\hline
\end{tabular}

Source: Author's own elaboration

"Renewable energy is almost carbon-neutral" (Ackah and Kizys, 2015: 1159; Akar, 2016). Findings of some studies showed that carbon emissions increase renewable energy consumption (Aguirre and Ibikunle, 2014; Apergis and Payne, 2014a, 2014b; Bengochea and Faet, 2012; Omri et al., 2015; Omri and Nguyen, 2014; Sadorsky, 2009b; Salim and Rafiq, 2012), however, some found the adverse effect of the emissions (Ackah and Kizys, 2015; da Silva et al., 2018; Marques and Fuinhas, 2011; Marques and Fuinhas, 2012). Environmental concerns, especially global warming and environmental awareness are emphasized as an important factor which reduces fossil fuel consumption and increases the renewable energy consumption (Aguirre and Ibikunle, 2014; Omri and Nguyen, 2014; Omri et al., 2015; Sadorsky, 2009b; Salim 
and Rafiq, 2012). Because the main reason of global warming and climate change is the high level of Greenhouse Gas emission release to the atmosphere (Marques et al., 2010), in the literature, emissions are used in the models in order to consider the environmental concerns and increase in emissions may be associated with higher use of renewables to achieve the emissions targets set by international agreements or determined by national administrative or regulatory agencies in their action plans which may lead to political pressure for renewable energy use (Bengochea and Faet, 2012; Chang et al., 2009; Marques and Fuinhas, 2011). Energy prices are other important factors influencing the renewable energy consumption and some of the studies (Ackah and Kizys, 2015; Apergis and Payne, 2014a, 2014b; Chang et al., 2009; da Silva et al., 2018; Omri and Nguyen, 2014; Omri et al., 2015; Sadorsky, 2009b) found statistically significant effects. As other energy sources, especially fossil fuels can be seen as substitutes to renewables, because as fossil fuel prices increase, the renewable energy consumption may increase (Apergis and Payne, 2014a, 2014b; Marques and Fuinhas, 2011; Marques et al., 2010; Omri and Nguyen, 2014; Omri et al., 2015; Sadorsky, 2009b; Salim and Rafiq, 2012). Also, the marginal cost of energy production using renewables are much lower compared to other energy resources, because of this, fossil fuel price increases may lead to increase in consumption of renewables. In addition, according to Chang et al. (2009), as there is a close relation between energy prices and inflation as well as inflation and economic growth, the use of renewables can reduce the cost push inflationary pressures resulted from the price increases in fossil fuels and decrease also possibility of stagflation. However, in most of the time, as renewables are subsidized because of high investment costs, this may also lead to an increase especially in electricity prices. Therefore, increase in electricity prices may decrease the use of renewables in electricity generation (Aguirre and Ibikunle, 2014; Carley, 2009; Marques et al., 2010). Technology lock-in may also lead to no change or decline in the share of renewables when fossil fuel prices rise. In addition, findings of the studies (Aguirre and Ibikunle, 2014; Carley, 2009; Gan and Smith, 2011; Kim and Park, 2016; Marques and Fuinhas, 2012; Marques et al., 2010) showed the significant impacts of various policy measures. After the implementation of Research and Development Programs in 1970's, Obligations and Tradable Certificates became popular in 2000's (Aguirre and Ibikunle, 2014). All these policy measures aim to increase the renewable energy deployment. Moreover, as pointed out by Aguirre and Ibikunle (2014) and Marques and Fuinhas (2011), social costs and benefits are not reflected in the market prices of energy sources which may create a disadvantageous situation for renewables making them more costly compared to fossil fuels. Akar (2016) emphasized the importance of government supports for the investment on renewables. Different government policies can be implemented in order to cope with the problems associated with the market failures, for example governments can use taxes on fossil fuels or subsidize the renewable energy sources by introducing different mechanisms based on taxes, quotas, feed-in tariffs, voluntary programs, tradable certificates or investment incentives for research and development (Aguirre and Ibikunle, 2014; Marques and Fuinhas, 2011; Pfeiffer and Mulder, 2013). Moreover, Marques and Fuinhas (2011) and Marques and Fuinhas (2012) emphasized that policy continuity and certainty are very important for renewable energy investments. Marques et al. (2010) points out the importance of institutions, such as EU membership. In the case of EU membership, common targets and the EU energy policies may encourage the renewable deployment. 
Moreover, Marques and Fuinhas (2011), Marques and Fuinhas (2012), Aguirre and Ibikunle (2014), and da Silva et al. (2018) found that higher energy use is associated with increase in the renewable energy consumption. The energy requirements can be met by various types of energy resources. Changes in energy use including electricity consumption may affect renewable energy consumption adversely or favorably (Aguirre and Ibikunle, 2014; Marques and Fuinhas, 2012; Marques et al., 2010; Pfeiffer and Mulder, 2013). As mentioned by Aguirre and Ibikunle (2014), if a country has severe energy security problems, this may push the country to rely heavily on fossil fuels and therefore, country decreases its renewable energy share. However, according to Marques and Fuinhas (2011), energy use as an indicator of economic development can increase the utilization of renewables. Energy dependency measured by energy imports was found to be an important driver which lead to an increase in the renewable energy consumption by Marques et al. (2010), whereas, decline in the renewable energy consumption by Marques and Fuinhas (2012) and da Silva et al. (2018). Deployment of renewable energy sources provides countries favorable trade balance effects, self-sufficiency and energy supply security by decreasing the energy import dependency because these energy sources are local sources including for example, wind, solar, geothermal, tidal and hydro energy sources and can substitute the imported fossil fuels (Ackah and Kizys, 2015; Aguirre and Ibikunle, 2014; da Silva et al., 2018; Marques and Fuinhas, 2011; Marques and Fuinhas, 2012; Marques et al., 2010). Moreover, decline in energy import dependency diminishes the impact of fossil fuel energy prices, in other words, countries' vulnerability to external shocks and restrictions imposed on economy because of fossil fuel reserve limits (Ackah and Kizys, 2015; da Silva et al., 2018). The findings of Marques et al. (2010), Marques and Fuinhas (2011), Marques and Fuinhas (2012) and Aguirre and Ibikunle (2014) indicate the negative effects of fossil fuel and nuclear contribution to electricity generation, i.e., lobby effect. According to Marques and Fuinhas (2011) and Marques et al. (2010), fossil fuels meet the energy requirements at low cost which is important for the economic growth and provides geo-strategic power to countries in various areas ranging from military to all economic fields. Also, fossil fuels can be easily stored and because of previous investments on technologies based on fossil fuels; their shares are not in negligible levels in installed capacity (Marques and Fuinhas, 2012). Moreover, energy production from natural gas and nuclear energy also result in lower GHG emissions compared to other alternatives such as coal and oil. Coal, natural gas, oil and nuclear shares in electricity generation are included in most of the studies in order to capture the influence of these fossil fuels on political and economic issues, i.e., lobby effect as well as the competition between renewables and traditional energy resources (Aguirre and Ibikunle, 2014). Lobby effect reflects the extent of pressure groups' influence on energy policies and also higher shares of these energy sources indicate the existence of scale economies which is essential for the feasibility of investment projects related to some technologies, such as nuclear (Marques and Fuinhas, 2011).

Among the studies shown in Table 1, Marques et al. (2010) found negative effects of fossil fuel and nuclear contribution to electricity generation and positive effects of energy imports, renewable energy potential, continuous commitment for renewable energy consumption, and various policy measures. Renewable energy potential, fossil fuel and nuclear contribution to electricity generation and continuous commitment for renewable energy consumption were 
also found to be important drivers by Aguirre and Ibikunle (2014) in addition to Kyoto Protocol ratification, energy use, industrial electricity price and carbon emissions. Higher renewable energy potential increases renewable energy consumption because of higher availability of resources (da Silva et al., 2018; Marques et al., 2010), however, quality and quantity of these potentials are important (Bird et al., 2005). The effect of continuous commitment for renewable energy consumption can be explained as follows. Large amount of investment in renewable energy including research and development may lead to continuity and persistency for the utilization of renewable energy sources (Marques and Fuinhas, 2011). Because, for the profitability of investments made previously, countries generally follow a strategy which focuses on the continuity of plans for the investment on renewables especially after crossing the takeoff phase of renewables development (Marques and Fuinhas, 2012). Moreover, previous renewable energy investments and infrastructure may lead to reduction in fixed costs creating economies of scale and higher profits with continuous commitment to renewables and these can increase the use of renewables (Aguirre and Ibikunle, 2014; Marques et al., 2010). Ratification of Kyoto protocol was taken as a boosting institutional factor and an incentive for renewable energy consumption as it is an important international agreement for the mitigation of greenhouse gas emissions putting obligations on countries for the emission reduction through the commitment of legally binding targets and may provide technology transfer (Aguirre and Ibikunle, 2014; da Silva et al., 2018). On the other hand, Pfeiffer and Mulder (2013) showed that real income, energy resource diversification and schooling level affect the renewable energy consumption statistically significant and positively; whereas, they found negative effects of trade openness, foreign direct investment, policy support programs, electricity consumption growth and fossil fuel production. They explained how energy resource diversification can affect renewable energy consumption as follows. There are differences among many technologies using different types of energy based on productivity and quality. As new technologies are immature, their productivity is low compared to traditional technologies mostly based on fossil fuels because of lack of knowledge about these technologies and also different technologies can complement each other as they have different properties changing with energy sources used, plant size and location, and skills needed in terms of management and organization (Pfeiffer and Mulder, 2013). Therefore, diversification among different technologies is inevitable. However, high share of technologies based on fossil fuels may deter deployment of renewable energy technologies because of vested interests of energy producer employing fossil fuel based technologies. As diversification level increases, the extent of vested interests declines and therefore, renewable energy consumption may increase. Human capital is another important factor which may affect use of renewables (Akay, 2016). Innovation as a result of education and environmental awareness gained through education may increase the renewable energy consumption (Ackah and Kizys, 2015). In addition, renewable energy technologies need expertise knowledge for installement, operation and research, development and innovation which can be gained through education (Pfeiffer and Mulder, 2013). Both trade openness and foreign trade firstly promote the production and consumption of tradable goods which may affect the energy consumption as well as renewable energy consumption and also, leads technology transfer including renewable energy technologies similar to foreign direct investments (Omri and Nguyen, 2014; Omri et al., 2015; Pfeiffer and Mulder, 2013). All these 
may increase the renewable energy consumption. On the other hand, in order to increase comparative advantage in the international trade, countries may decrease the energy prices or relax regulatory restrictions related to environment (Pfeiffer and Mulder, 2013) which can influence renewable energy consumption, adversely. According to Pfeiffer and Mulder (2013), fossil fuel production may deter the deployment of renewable energy. If a country has high potential of a fossil fuel, then this can decrease its price domestically. Thus, due to low cost, energy security concern and low environmental awareness, in this case energy generation may depend mostly on fossil fuels, which may be an impediment for the renewable energy technology adoption and therefore affect renewable energy consumption, negatively. Different from other studies, analysis of Kim and Park (2016) indicate that financial market development, international financing and electricity generation share are important drivers of renewable energy consumption besides policy variables, whereas, study of Carley (2009) shows the statistical significance of other factors' negative impacts, such as, per capita electricity consumption, petroleum and coal manufacturing shares, deregulation, renewable energy potential and tax incentive program through its effect on renewable energy consumption of households and microgeneration which affect the share of renewables slightly, only in addition to the positive effects of real income and policy measures and negative effect of electricity price. Access to finance is another important factor which influences renewable energy consumption to a great extent and both financial aid and financial development encourage the renewable energy investment (Pfeiffer and Mulder, 2013). Kim and Park (2016) provide detailed explanations for the effects of both equity and credit market development on renewable energy investments, therefore, consumption. Briefly, the mechanism can be explained as follows. As renewable energy investments are characterized by high initial investment costs, existence of information asymmetry between investors and financing institutions which create high information costs as well as high specificity of assets, external financing becomes costly. Financial sector (equity and credit markets) development ensures accessibility of external financing by the promotion of high technology projects, decreasing information asymmetry and eliminating moral hazard and adverse selection problems which are based on modern contract theories. On the other hand, international financing is independent from financial development of countries and can be an alternative finance mechanism for renewable energy projects (Kim and Park, 2016). Electricity generation share was employed by Kim and Park (2016) to control for the heterogeneity among sectors and also as a proxy for return on investment because it may indicate the degree of effect coming from capacity factors, technical problems, technology-specific characteristics and installed capacity. Moreover, according to Carley (2009), effect of per capita electricity consumption may change depending on the load curves and electricity demand type (for example, base load or peak load) because base load is generally met by centralized fossil fuelled power plants, in addition, petroleum and coal manufacturing shares show also lobby effect of fossil fuel energy sources which may influence the renewable energy consumption as higher shares of petroleum and coal manufacturing can be used as indicator for power of pressure groups. Deregulation may increase use of renewables as a result of incentives for research and development in renewable technologies, liberalization of supply and demand side of the energy market or use of fossil fuels because of lower 
investment costs of traditional technologies based on fossil fuels and economies of scale resulted from centralized generation (Aguirre and Ibikunle, 2014; Carley, 2009).

Other factors and their effects can be summarized as follows. The previous studies showed the statistically significant and positive impacts of energy resource depletion (Ackah and Kizys, 2015), trade openness (Akar, 2016; Omri and Nguyen, 2014), natural gas rents (Akar, 2016), economic growth (Sadorsky, 2009a), and foreign trade (Omri et al., 2015). Renewable energy is inexhaustible in contrast to fossil fuels (Ackah and Kizys, 2015; Akar, 2016), therefore this advantage is expected to lead to increase in the renewable energy consumption. Akar (2016) included coal, oil and natural gas rents to understand the influence of fossil energy sources' potential and high potential may have adverse effect on the renewable energy consumption because of substitutability between renewables and fossil fuels. Economic growth may increase the renewable energy consumption because higher growth needs higher energy consumption and considering the concerns related to climate change and environmental issues, higher energy consumption should be met by renewables (Omri and Nguyen, 2014; Omri et al., 2015). On the other hand,-negative effects of economic growth (Akar, 2016) and population growth (da Silva et al., 2018) were found by some studies. Akar (2016) explained this finding as the insufficient level of economic growth in Balkan countries for supporting the highly expensive renewable energy investments. Also, in order to meet higher electricity demand resulted from population growth, countries will increase the base load electricity generation which is mostly based on fossil fuels or electricity generation based on renewables (Carley, 2009; da Silva et al., 2018) depending on the economic situation of a country. For further explanation for these results, one can refer to the related studies. Moreover, Ackah and Kizys (2015) considered the impacts of two important production factors (capital and labor) which can be regarded as complements to energy consumption and as energy demand is a derived demand which necessitates the use of capital goods, higher levels of employment and capital formation may increase renewable energy consumption taking into account the environmental concerns and increase in environmental awareness.

Following Chang et al. (2009), this study employs Panel Threshold Regression Model (PTR) using larger number of economic factors which are expected to influence renewable energy consumption. The contribution of this study is the analysis of determinants of renewable energy consumption in the context of a nonlinear model by using data on global sample of countries over the period from 1990 to 2012. The paper is organized as follows. After this brief introduction, methodological issues are discussed in Section 2. Section 3 presents information on data and empirical results. Last section concludes with policy recommendations.

\section{Model and Methodology}

This study employs Panel Threshold Regression Model given in equation (1);

renewable $=D_{\mu} \mu+x \beta_{1} I(\lg d p c \leq \gamma)+x \beta_{2} I(\lg d p c>\gamma)+\varepsilon$ 
where, $\mathrm{x}$ shows the explanatory variables given by $x=$ (eaccess, lgdpc, fdi, ecoal, engas, eoil, enuclear, lcpi, openness, urban, crents, orents, ngrents, capital, emix, labor, depletion, enuse, enimports, ghg, commitment) and $\varepsilon$ iid $\left(0, \sigma^{2}\right)$. Threshold variable is chosen as natural logarithm of real Gross domestic product per capita (lgdpc) in order to distinguish the effects of various factors based on income level similar to Chang et al. (2009) in which the impact of energy prices on the renewable energy consumption is examined by taking the economic growth as the threshold variable. $\gamma$ is the threshold parameter. The model allows for heterogeneity across countries by introducing fixed effects $\left(D_{\mu} \mu\right)$ into the specification. In equation (1), renewable energy consumption share out of total final energy consumption (renewable) is determined by the following factors: electricity access (eaccess), natural logarithm of real Gross domestic product per capita (lgdpc), foreign direct investment (fdi), share of coal in the electricity production (ecoal), share of natural gas in the electricity production (engas), share of oil in the electricity production (eoil), share of nuclear in the electricity production (enuclear), logarithm of consumer price index (lcpi), trade openness (openness), urbanization ratio (urban), coal rents (crents), oil rents (orents), natural gas rents (ngrents), gross capital formation (capital), energy resource diversification in the electricity generation (emix), employment (labor), energy resource depletion (depletion), energy use (enuse), energy imports (enimports), Greenhouse Gas emissions (ghg), continuous commitment to renewable energy consumption (commitment). The inclusion of shares of coal, natural gas, oil and nuclear in the electricity production show the effect of the fossil fuel and nuclear energy dominance, therefore lobby effect of these energy sources (Marques et al., 2010). lcpi is included as a proxy for energy prices as for some countries, it is difficult to obtain data on energy prices, especially for African countries (Ackah and Kizys, 2015). Following Akar (2016), in order to explain the impact of fossil energy sources potential, we add coal rents, oil rents and natural gas rents. Negative effects of these variables (ecoal, engas, eoil and enuclear, lcpi, crents, orents, ngrents) are expected on the share of renewable energy consumption. High energy prices may reduce the renewable energy consumption directly based on inverse relation between price and demand in the theory. Moreover, high potential and share of fossil energy sources in the electricity generation may deter the investments on renewable energy sources which can influence the renewable energy consumption.

On the other hand, a priori, we expect positive effects of higher level of electricity access, real GDP per capita, foreign direct investment, trade openness, urbanization ratio, gross capital formation, energy resource diversification in the electricity generation, employment, energy resource depletion, energy imports, greenhouse gas emissions and continuous commitment. As the percentage of population having access to electricity increase, we expect higher level of renewable energy consumption because of environmental concerns. Increased economic activity leads to increase in the energy consumption and also high income countries may be much more eager to support the renewable energy investments leading to an increase in the renewable energy consumption. By international trade and foreign direct investment, renewable energy technology can be easily diffused across countries which can increase also renewable energy consumption (Pfeiffer and Mulder, 2013). Moreover, urbanization can lead 
to increase in energy consumption as well as renewable energy consumption by ensuring easy access to electricity and electrical devices and machines. Assuming that as a factor of production, energy is complement to capital and labor in the economy, higher levels of employment and capital formation are associated with increase in renewable energy consumption. Energy resource diversification in the electricity generation indicates if there exists any dominance of energy resource in the electricity generation as a whole and if one energy source is highly used in the electricity generation, one can expect higher intention to keep its share, which leads to lower level of renewable energy consumption (Pfeiffer and Mulder, 2013). Therefore, as the diversification increases, renewable energy consumption also rises. On the other hand, energy resource depletion of coal, natural gas and oil can also contribute to the use of renewable resources (Ackah and Kizys, 2015) as countries tend to shift to alternative energy sources other than fossil fuels. Energy imports show the country's external dependency on energy. In order to decrease the dependency therefore to ensure energy supply security as well as to mitigate greenhouse gas emissions considering the environmental impacts of fossil fuels, countries can attempt to use renewable energy as an alternative source (Marques and Fuinhas, 2011; Marques and Fuinhas, 2012). The positive and significant effect of greenhouse gas emissions reflect the society's awareness related to the environmental issues (Marques and Fuinhas, 2011). Lastly, continuous commitment to renewable energy is included to control for the scale economies resulted from investment and infrastructure made previously which lead to reduction in fixed costs and therefore increase in the renewable energy consumption (Aguirre and Ibikunle, 2014; Marques and Fuinhas, 2012; Marques et al., 2010). For energy use, as the countries can satisfy their energy requirements from fossil energy, nuclear or renewable energy or mix of all, the sign of effect cannot be determined a priori (Marques et al., 2010).

For the detailed information on estimation, one can refer to Candelon et al. (2013). In order to test nonlinear model against linear model $\left(H_{0}: \beta_{1}=\beta_{2}\right)$ and assuming only two regimes, the following approximate LR test is used in equation (2);

$$
F_{1}=S_{0}-S_{1}(\hat{\gamma}) / \hat{\sigma}^{2}
$$

where, $S_{0}$ and $S_{1}(\hat{\gamma})$ are the sum of squared errors obtained from linear model and nonlinear model with two regimes. $\hat{\gamma}$ and $\hat{\sigma}^{2}$ are the estimates of threshold parameter and $\sigma^{2}$. Asymptotic distribution of the test statistic is obtained by bootstrap procedure. The test statistics for 3 and 4 regimes can be found in Candelon et al. (2013).

\section{Data}

In the analysis, we use balanced panel data on 58 countries namely Australia, Austria, Bangladesh, Bolivia, Botswana, Brazil, Bulgaria, Cameroon, Canada, Colombia, Cote d'Ivoire, Denmark, Dominican Republic, Ecuador, Egypt Arab Rep., El Salvador, Finland, France, 
Gabon, Germany, Ghana, Guatemala, Honduras, Iceland, India, Indonesia, Ireland, Israel, Italy, Japan, Jordan, Kenya, Malaysia, Mexico, Morocco, Netherlands, New Zealand, Nigeria, Norway, Pakistan, Panama, Peru, Philippines, Poland, Portugal, Senegal, Spain, Sri Lanka, Sudan, Sweden, Switzerland, Thailand, Tunisia, Turkey, United Kingdom, United States, Uruguay and Yemen, Rep. over the period from 1990 to 2012. The period and number of countries are determined based on the data availability on all the variables. For example, total greenhouse gas emissions (kt of CO2 equivalent) is available only up to 2012. The dataset includes Access to electricity (\% of population); GDP (current US\$); GDP per capita (constant 2010 US\$); Foreign direct investment, net inflows (\% of GDP); Energy use (kg of oil equivalent per capita); Energy imports, net (\% of energy use); Electricity production from coal sources (\% of total); Electricity production from natural gas sources (\% of total); Electricity production from oil sources (\% of total); Electricity production from nuclear sources (\% of total); Electricity production from renewable sources, excluding hydroelectric (\% of total); Consumer price index $(2010=100)$; Trade (\% of GDP); Renewable energy consumption (\% of total final energy consumption); Urban population (\% of total); Total greenhouse gas emissions (kt of CO2 equivalent); Renewable electricity output (\% of total electricity output); Labor force, total; Coal rents (\% of GDP); Adjusted savings: energy depletion (current US\$); Oil rents (\% of GDP); Natural gas rents (\% of GDP); Gross capital formation (\% of GDP) and Population, total. All the data is obtained from World Bank World Development Indicators Database. The following calculations are performed before the estimation of empirical models;

1. Index for energy resource diversification in the electricity generation (emix) is given by equation (3) and takes the values between 0 and 100. 0 shows that the country depends on only one energy source for the generation of electricity and values close to 100 indicate high level of resource diversification for the electricity generation.

$$
\text { emix }_{i t}=100 \times\left(1-\sum_{j}\left(\text { Share }_{j, i t} / 100\right)^{2}\right) \text { for country } i=1,2, \ldots, 58 \text { and year } t=1990, \ldots, 2012
$$

where, Share ${ }_{j, i t}$ shows the electricity production from coal sources (\% of total), electricity production from natural gas sources ( $\%$ of total), electricity production from oil sources (\% of total), electricity production from nuclear sources (\% of total) and electricity production from renewable sources, excluding hydroelectric (\% of total), respectively.

2. Employment (labor) is calculated by dividing Labor force, total to Population, total, and then multiplied by 100 .

3. Energy resource depletion (depletion) is ratio of Adjusted savings: energy depletion (current US\$) to GDP (current US\$) and then multiplied by 100.

4. Energy use as a percentage of GDP (enuse) is given by the ratio of Energy use (kg of oil equivalent per capita) to GDP per capita (constant 2010 US\$) multiplied by 100.

5. Energy imports as a percentage of GDP (enimports) is given by equation (4); 
enimports $=100 \times$ Energy imports, net $(\%$ of energy use $) \times\left(\frac{\text { Energy use }(\mathrm{kg} \text { of oil equivalent per capita })}{\text { GDP per capita }(\text { constant } 2010 \text { US })}\right)$

(4)

6. Greenhouse Gas emissions as a percentage of GDP (ghg) is calculated as follows in equation (5);

$$
g h g=100 \times\left(\frac{\text { Total greenhouse gas emissions }(k t \text { of CO2 equivalent })}{\text { GDP per capita }(\text { constant } 2010 \text { US } \$) \times \text { Population, total }}\right)
$$

7. Continuous commitment to renewable energy consumption (commitment) is a dummy variable taking the value of 1 if renewable energy consumption (\% of total final energy consumption) exceeds $20 \%$ and 0 , otherwise.

\section{Empirical Results}

We estimate linear (panel data model with fixed effects) and nonlinear models (PTR model). The estimation results are given in Table $2 . F_{1}$ statistic indicates the presence of nonlinearity in the model. We also test for higher order of nonlinearity, but these models with more than two regimes are rejected. Therefore, our interpretations are based on the model with only one threshold in which threshold variable is chosen as lgdpc. Threshold parameter is estimated as 7.3317. Therefore, the effects of each variable is different for GDP per capita (constant 2010 US\$) lower than 1527.977 and higher than this value. Estimation results suggest that for both regimes, the coefficients on eaccess, lcpi, urban, enuse, enimports and commitment are statistically significant with the same signs but difference is related to their magnitudes. The effects of these factors are larger for lower regime except urbanization. Previous studies also found positive effects of lcpi which is used as a proxy for energy prices in this study (real oil prices (Apergis and Payne, 2014a, 2014b; Omri et al., 2015; Sadorsky, 2009b) and real coal prices (Apergis and Payne, 2014b)), enuse (Marques et al., 2010), enimports (Marques et al., 2010) and commitment (Aguirre and Ibikunle, 2014; Marques et al., 2010). But different than our findings, Aguirre and Ibikunle (2014) found that energy use decreases the use of renewable energy. Regardless of the state of economy, findings in this study indicate that countries increase the share of renewables in their total energy consumption as energy use increases.

On the other hand, lgdpc, enuclear, openness, orents and depletion affect the renewable energy consumption statistically significant in both regimes with different signs and size. In this case also the magnitudes of the effects are higher for lower regime in absolute terms with two exceptions: orents and depletion. 
Table 2. Estimation Results of Linear and Nonlinear Model

\begin{tabular}{|c|c|c|c|c|c|c|}
\hline \multirow[b]{3}{*}{ renewable } & \multirow{2}{*}{\multicolumn{2}{|c|}{ Linear Model }} & \multicolumn{2}{|c|}{ PTR Model } & \multirow{2}{*}{\multicolumn{2}{|c|}{ Upper Regime $q(\mathrm{t})>7.3317$}} \\
\hline & & & \multicolumn{2}{|c|}{ Lower Regime $\mathrm{q}(\mathrm{t})<=7.3317$} & & \\
\hline & Coefficient & t statistic & Coefficient & t statistic & Coefficient & t statistic \\
\hline eaccess & $-0.41827^{* * *}$ & $(-18.48)$ & $-0.3607^{* * *}$ & $(-6.40)$ & $-0.2994^{* * *}$ & $(-10.95)$ \\
\hline $\operatorname{lgdpc}$ & $3.920433^{* * *}$ & $(3.41)$ & $-17.5555^{* * *}$ & $(-5.26)$ & $9.202^{* * *}$ & $(5.40)$ \\
\hline fdi & -0.01033 & $(-0.41)$ & $-0.3077 * * *$ & $(-3.30)$ & 0.0084 & $(0.46)$ \\
\hline ecoal & $-0.17752^{* * *}$ & $(-8.45)$ & 0.0577 & $(0.18)$ & $-0.211^{* * * *}$ & $(-12.00)$ \\
\hline engas & $-0.12501^{* * *}$ & $(-6.90)$ & -0.0344 & $(-0.95)$ & $-0.237^{* * *}$ & $(-11.30)$ \\
\hline eoil & $-0.16231^{* * *}$ & $(-10.56)$ & -0.0123 & $(-0.40)$ & $-0.262^{* * *}$ & $(-13.59)$ \\
\hline enuclear & $-0.32944^{* * *}$ & $(-5.91)$ & $1.4416^{* * *}$ & $(3.67)$ & $-0.4103^{* * *}$ & $(-8.93)$ \\
\hline Icpi & $0.749137^{* * *}$ & $(4.97)$ & $3.168^{* * *}$ & $(7.28)$ & $0.5994^{* * *}$ & $(3.25)$ \\
\hline openness & 0.00903 & $(0.94)$ & $-0.081^{* * *}$ & $(-3.09)$ & $0.0282^{* * *}$ & (3.13) \\
\hline urban & 0.021759 & $(0.42)$ & $-0.196^{* *}$ & $(-2.12)$ & $-0.225^{* * *}$ & $(-4.34)$ \\
\hline crents & -0.39918 & $(-0.85)$ & $4.5144^{* * *}$ & (3.77) & -0.1463 & $(-0.54)$ \\
\hline orents & -0.11341 & $(-0.84)$ & $-0.2594^{*}$ & $(-1.69)$ & $0.6689^{* * *}$ & (3.39) \\
\hline ngrents & -0.25618 & $(-0.89)$ & 0.4954 & $(0.51)$ & 0.2431 & $(0.92)$ \\
\hline capital & 0.02146 & $(0.78)$ & $0.3657^{* * *}$ & $(4.56)$ & 0.0221 & $(0.74)$ \\
\hline emix & $0.02865^{* *}$ & $(2.27)$ & -0.0208 & $(-0.74)$ & $0.0461^{* * *}$ & (3.81) \\
\hline labor & $-0.21229^{* * *}$ & $(-3.61)$ & 0.3457 & (1.39) & $-0.4202^{* * *}$ & $(-6.73)$ \\
\hline depletion & 0.092198 & $(0.49)$ & $0.4553^{*}$ & $(1.92)$ & $-0.8663^{* * *}$ & $(-3.17)$ \\
\hline enuse & $0.29724^{* * *}$ & $(8.96)$ & $0.4589^{* * *}$ & (7.12) & $0.242^{* * *}$ & (3.28) \\
\hline enimports & $0.097559^{* * *}$ & (5.36) & $0.1613^{* * *}$ & (3.98) & $0.0687^{* *}$ & $(2.45)$ \\
\hline ghg & 490.4635 & $(0.70)$ & -453.747 & $(-0.57)$ & 171.1785 & $(0.15)$ \\
\hline commitment & $5.063627^{* * *}$ & $(8.02)$ & $155.0248^{* * *}$ & $(5.42)$ & $3.9984^{* * *}$ & (6.97) \\
\hline$F$ test for Fes ${ }^{1}$ & & $172.4^{* * *}$ & F1 test statist & & $474.8061^{* * *}$ & \\
\hline
\end{tabular}

Comparisons with previous studies show that the following results are in line with these findings: positive effects of lgdpc for upper regime (Ackah and Kizys, 2015; Apergis and Payne, 2014a, 2014b; Carley, 2009; Omri et al., 2015; Omri and Nguyen, 2014; Pfeiffer and Mulder, 2013; Sadorsky, 2009a, 2009b; Salim and Rafiq, 2012), openness for upper regime (Akar, 2016; Omri and Nguyen, 2014) and depletion for lower regime (Ackah and Kizys, 2015) and negative effects of enuclear for upper regime (Aguirre and Ibikunle, 2014; Marques and Fuinhas, 2012; Marques et al., 2010) and openness for lower regime (Pfeiffer and Mulder, 2013). On the contrary, Akar (2016) found statistically insignificant effect of orents. There are also some variables which have statistically significant effect in only one regime. The coefficients on fdi, crents and capital are statistically significant in the lower regime, whereas, results show that the coefficients associated with ecoal, engas, eoil, emix and labor are statistically significant in the upper regime. Pfeiffer and Mulder (2013) also found that as emix increases, renewable energy consumption increases too. Similar to our results, some studies showed negative effects of ecoal, engas and eoil (Aguirre and Ibikunle, 2014; Marques and Fuinhas, 2012; Marques et al., 2010) and fdi (Pfeiffer and Mulder, 2013). Lastly, results indicate that ghg and ngrents does not affect the renewable energy consumption share. Previous studies, such as Marques and Fuinhas (2011) and Gan and Smith (2011) also found that emission levels are not enough to encourage the use of renewable energy resources. However, the results of da Silva et al. (2018), Ackah and Kizys (2015) and Marques and Fuinhas (2012) show the negative and significant effects of emissions and some studies found the positive effects (Aguirre and Ibikunle, 2014; Apergis and 
Payne, 2014a, 2014b; Bengochea and Faet, 2012; Omri et al., 2015; Omri and Nguyen, 2014; Sadorsky, 2009b; Salim and Rafiq, 2012). Findings of Akar (2016) indicate statistically significant and positive impact of ngrents which is different from the results of this study.

Moreover, some of the findings are contrary to our expectations. We expect to have the opposite signs on the coefficients of eaccess, lcpi, urban in both regimes; lgdpc, fdi, enuclear, openness, crents for lower regime and orents, labor and depletion for upper regime. According to the results, lower electricity access, higher energy prices and lower level of urbanization lead to higher renewable energy consumption. Technologies based on renewable energy sources allow for the decentralization of energy services; therefore, as access to electricity becomes difficult or impossible technically, the renewable energy consumption may increase also. In rural areas also, renewable energy may be preferred as these areas may not have access to centralized energy services. The positive effect of energy prices are in line with the findings of the previous literature (see for example, Apergis and Payne (2014b), Apergis and Payne (2014a), Omri et al. (2015) and Sadorsky (2009b)), however, in contrast to our finding, the impacts of energy prices are found to be negative in some of the studies in the literature (for example, da Silva et al. (2018), Carley (2009), and Ackah and Kizys (2015)). In this analysis, lcpi is used as a proxy for energy prices and as the findings show positive effect of lcpi on renewable energy consumption, one can infer that lcpi reflect mostly the fossil fuel prices. When fossil fuel prices increase, countries shift to the renewable energy resources in order to meet their energy demand, i.e., they substitute fossil fuels with renewable energy resources. For the lower regime, income per capita, foreign direct investment and trade openness affect the renewable energy consumption, negatively. In the lower regime, as income per capita increases, countries meet their energy demand with the fossil fuels much more compared to renewable energy sources which further lead to a decline in the share of renewables. Below the threshold level of income per capita, foreign direct investment and trade openness can lead to dissemination of technologies mostly based on fossil fuels causing the share of renewable to decline. Positive effects of nuclear energy share and coal rents are found. One explanation of these results can be such that the countries with high coal rents can invest their earnings from coal to renewable energy technology and as the countries attempt to decarbonize their electricity generation sector by increasing the share of nuclear energy, they also increase their renewable energy consumption. Results for upper regime suggest positive effect of orents and negative effects of labor and depletion. Oil earnings can be invested in renewable energy technologies and as the resource depletion increase, countries try to decrease their overall energy consumption and therefore renewable energy consumption also but this decrease may be reflected more on the renewable energy consumption. Negative effect of labor indicates that labor and renewable energy can be substitute to each other.

\section{Conclusions}

Energy is an essential input for industry, electricity generation, transportation, heating and cooling. Residential and commercial sector also use energy for various purposes. However, because of the adverse effects of conventional energy resources utilization on environment, the 
countries attempt to use other alternative energy resources and renewable energy is one of these options. There are also many reasons for the consumption of renewable energy. Therefore, this study analyzes the determinants of renewable energy consumption by using panel data on a large number of countries and a nonlinear model. This analysis may also help us to implement suitable economic policies which can stimulate the renewable energy investments by taking into account the factors affecting the investments. However, determinants of renewable energy consumption can vary across countries based on their income level as their priority may be different and also, the financing ability of countries may change. High income countries may finance costly renewable energy projects and response to income increases by increasing their renewable energy share because of these countries' high awareness of environmental issues and alternative options for energy supply (Gan and Smith, 2011). However, for low income countries, renewable energy may not be priority for them, when income increases; they may prefer to make investment related to health, education and other important areas rather than energy sector. Moreover, even they prefer to make energy investment, for low income countries, economic growth may be much more important compared to environmental sustainability, as fossil fuels are much more cost competitive compared to renewables, fossil fuels can be used to promote economic growth. Furthermore, instead of using country categories based on income level defined by international institutions, this study employs a threshold model to consider the difference between low and high income countries as category of countries may change over time which may be ignored by employing the classifications of a given period proposed by international institutions. By considering nonlinear effects of many factors based on income levels of countries as high and low income countries categorized by a threshold level estimated endogenously, this method is expected to give much better results in this respect. Our results show that one should account for the nonlinearity in the model. After some threshold of per capita income, the influences of the factors differ between two regimes which are upper (high income) and lower (low income) regimes. For example, the lobby effect of traditional energy resources are found in only upper regime. In addition, per capita income have negative and higher influence for the lower regime compared to its positive effect for the upper regime. Thus, while making renewable energy policies, the policy makers should consider the nonlinear behavior of renewable energy consumption. In addition, one can conclude that environmental concerns are not much more important than the other factors for shift to the renewable energy resources which is contrary to the mostly mentioned claimed reasons such as climate change. Also, as income and price are significant drivers, market forces seem to affect the renewable energy consumption. In order to stimulate the use of renewable energy resources, taxing policies for fossil fuel consumption can be implemented. For high income countries, international trade plays an important role for the dissemination of renewable energy technologies and therefore increases renewable energy consumption. Because of this, economic policies should focus on the promotion of international trade globally and trade barriers should be removed. However, as a future study, the effects of various policy measures can be analyzed thoroughly. 


\section{References}

Ackah, I., \& Kizys, R. (2015). Green growth in oil producing African countries: A panel data analysis of renewable energy demand. Renewable and Sustainable Energy Reviews, 50, 1157-1166. doi:https://doi.org/10.1016/j.rser.2015.05.030

Aguirre, M., \& Ibikunle, G. (2014). Determinants of renewable energy growth: A global sample analysis. Energy Policy, 69, 374-384.

Akar, B. G. (2016). The Determinants Of Renewable Energy Consumption: An Empirical Analysis For The Balkans. European Scientific Journal, 12(11), 594-607. doi:10.19044/esj.2016.v12n11p594

Apergis, N., \& Payne, J. E. (2014a). The causal dynamics between renewable energy, real GDP, emissions and oil prices: evidence from OECD countries. Applied Economics, 46(36), 4519-4525. doi:10.1080/00036846.2014.964834

Apergis, N., \& Payne, J. E. (2014b). Renewable energy, output, CO2 emissions, and fossil fuel prices in Central America: Evidence from a nonlinear panel smooth transition vector error correction model. Energy Economics, 42, 226-232. doi:https://doi.org/10.1016/j.eneco.2014.01.003

Bengochea, A., \& Faet, O. (2012). Renewable energies and CO2 emissions in the European Union. Energy Sources, Part B: Economics, Planning, and Policy, 7(2), 121-130. doi:10.1080/15567240902744635

Bird, L., Bolinger, M., Gagliano, T., Wiser, R., Brown, M., \& Parsons, B. (2005). Policies and market factors driving wind power development in the United States. Energy Policy, 33(11), 1397-1407. https://doi.org/10.1016/j.enpol.2003.12.018

Candelon, B., Colletaz, G., \& Hurlin, C. (2013). Network effects and infrastructure productivity in developing countries. Oxford Bulletin of Economics and Statistics, 75(6), 887-913. doi:10.1111/j.1468-0084.2012.00722.x

Carley, S. (2009). State renewable energy electricity policies: An empirical evaluation of $\begin{array}{llll}\text { effectiveness. } & \text { Energy }\end{array}$ doi:http://dx.doi.org/10.1016/j.enpol.2009.03.062

Chang, T. H., Huang, C. M., \& Lee, M. C. (2009). Threshold effect of the economic growth rate on the renewable energy development from a change in energy price: Evidence from OECD countries. Energy Policy, 37(12), 5796-5802. 
da Silva, P. P., Cerqueira, P. A., \& Ogbe, W. (2018). Determinants of renewable energy growth in Sub-Saharan Africa: Evidence from panel ARDL. Energy, 156, 45-54. doi:https://doi.org/10.1016/j.energy.2018.05.068

Gan, J. B., \& Smith, C. T. (2011). Drivers for renewable energy: A comparison among OECD countries. Biomass \& Bioenergy, 35(11), 4497-4503. doi:10.1016/j.biombioe.2011.03.022

Kim, J., \& Park, K. (2016). Financial development and deployment of renewable energy $\begin{array}{llll}\text { technologies. Energy } & \text { Economics, }\end{array}$ doi:https://doi.org/10.1016/j.eneco.2016.08.012

Marques, A. C., \& Fuinhas, J. A. (2011). Drivers promoting renewable energy: A dynamic panel approach. Renewable \& Sustainable Energy Reviews, 15(3), 1601-1608. doi:10.1016/j.rser.2010.11.048

Marques, A. C., \& Fuinhas, J. A. (2012). Are public policies towards renewables successful? Evidence from European countries. Renewable Energy, 44, 109-118. doi:https://doi.org/10.1016/j.renene.2012.01.007

Marques, A. C., Fuinhas, J. A., \& Pires Manso, J. R. (2010). Motivations driving renewable energy in European countries: A panel data approach. Energy Policy, 38(11), 6877-6885. doi:http://dx.doi.org/10.1016/j.enpol.2010.07.003

Omri, A., Daly, S., \& Nguyen, D. K. (2015). A robust analysis of the relationship between renewable energy consumption and its main drivers. Applied Economics, 47(28), 29132923.

Omri, A., \& Nguyen, D. K. (2014). On the determinants of renewable energy consumption: International Evidence. $\quad$ Energy, $\quad$ 52, doi:https://doi.org/10.1016/j.energy.2014.05.081

Pfeiffer, B., \& Mulder, P. (2013). Explaining the diffusion of renewable energy technology in developing countries. Energy Economics, 40, 285-296. doi:https://doi.org/10.1016/j.eneco.2013.07.005

REN21. (2014). Renewables 2014 Global Status Report. Paris: REN21 Secretariat.

REN21. (2015). Renewables 2015 Global Status Report. Paris: REN21 Secretariat.

REN21. (2017). Renewables 2017 Global Status Report. Paris: REN21 Secretariat.

Sadorsky, P. (2009a). Renewable energy consumption and income in emerging economies. Energy Policy, 37(10), 4021-4028. doi:http://dx.doi.org/10.1016/j.enpol.2009.05.003 
Sadorsky, P. (2009b). Renewable energy consumption, CO2 emissions and oil prices in the G7 countries. Energy Economics, 31(3), 456-462. doi:http://dx.doi.org/10.1016/j.eneco.2008.12.010

Salim, R. A., \& Rafiq, S. (2012). Why do some emerging economies proactively accelerate the adoption of renewable energy? Energy Economics, 34(4), 1051-1057. doi:https://doi.org/10.1016/j.eneco.2011.08.015

Sawin, J. (2004). National policy instruments: Policy lessons for the advancement and diffusion of renewable energy technologies around the world. (Thematic Background Paper). International Conference for Renewables, Bonn. 